\title{
Radioprotective Effect of Nigella Sativa Oil on Heart Tissues of Rats Exposed to Irradition
}

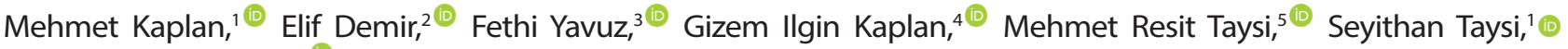 \\ Mehmet Murat Sucu' ${ }^{\circledR}$ \\ Gaziantep University School of Medicine, Department of Cardiology,' Gaziantep - Turkey \\ Division of Biochemistry, Harran University, College of Health, ${ }^{2}$ Sanlıurfa - Turkey \\ Adana City Training \& Research Hospital, Department of Cardiology, ${ }^{3}$ Adana - Turkey \\ Ersin Arslan Training \& Research Hospital, Department of Internal Medicine, ${ }^{4}$ Gaziantep - Turkey \\ Faculty of Agriculture, Bingol University, ${ }^{5}$ Bingol - Turkey
}

\section{Abstract}

Background: Various studies are ongoing related to the radioprotective agents. Herbal preparations are currently becoming popular because of their beneficial effects with fewer side effects compared to the synthetic/semisynthetic medicines, and Nigella sativa oil (NSO) is only one of them.

Objective: To investigate NSO for its antioxidant effects on the heart tissue of rats exposed to ionizing radiation (IR).

Methods: Thirty six male albino Wistar rats, divided into four groups, were designated to group I (IR plus NSO group) that received both 5 Gray of gamma IR to total cranium and NSO; group II (IR alone group) that received IR plus saline, group III (control group of NSO) that received saline and did not receive NSO or IR; group IV (control group) that received only sham IR. Alterations in Total antioxidant status (TAS) and Total oxidant status (TOS), Oxidative stres index (OSI), Sulhydryl group (SH), Lipid hydroperoxide (LOOH), Paraoxonase (PON) levels, Arylesterase (ARE) and Ceruloplasmin (CER) activities in homogenized heart tissue of rats were measured by biochemical methods.

Results: In heart tissue of the rats in the IR alone group (group II) LOOH, TOS and OSI levels were found to be higher, ARE activity and TAS level were found to be lower than all of the other groups $(\mathrm{p}<0.01)$. These results also support that IR increases oxidative stress and NSO's protective effect.

Conclusion: NSO would reduce the oxidative damage in the irradiated heart tissue in the experimental rat model.

Keywords: Rats; Radiation; Radiation, Effects; Nigella Sativa Oil; Plants, Medicinal; Anti-Inflammatory Agents/ therapeutic use.

\section{Introduction}

Radiotherapy is an important treatment method for a wide variety of malignancies. Ionizing radiation (IR) is known to generate free radicals in irradiated tissues. ${ }^{1}$ Mammalian cells have both enzymatic and non-enzymatic cleansing systems to remove reactive oxygen species (ROS) and reactive nitrogen species (RNS), respectively. ${ }^{2}$ An imbalance favoring the prooxidants and disfavoring the antioxidants, potentially leading to damage, has been called "oxidative stress."3
Efforts to reduce the toxicity of irradiation to normal tissues, organs, and cells have led to the investigation of cytoprotective agents. ${ }^{4}$ Many dietary components may have either direct antioxidant activity, such as flavonoids, melatonin, nigella sativa oil (NSO), and thymoquinone(TQ), ${ }^{5}$ or indirect antioxidant activity, such as zinc, ${ }^{6}$ manganese, and selenium. ${ }^{7} \mathrm{NSO}$ is commonly known as 'black seed' and has strong antioxidant properties against oxidative damage. ${ }^{8}$ Many studies have reported that it has various pharmacological properties, including 
antioxidant, hepatoprotective, neuroprotective, antidiabetic, anti-inflammatory, nephroprotective, and anticarcinogenic. ${ }^{9}$ This study aimed to investigate the effects of NSO supplementation on oxidant/antioxidant parameters simultaneously in the heart tissue of rats exposed to IR.

\section{Methods}

\section{Rats and experiments}

Thirty six male albino Wistar rats, 10-12 weeks old, weighing $200625 \mathrm{~g}$ at the time of radiation, were used for the experiment. Power analysis was performed for the study, and it was found to be 0.80 . The rats were quarantined for at least one week before gamma IR and fed standard laboratory chow and water ad libitum. All rats were divided into four groups with equal probability by simple randomization and designated to group I (IR plus NSO group), which received both 5 Gray of gamma IR to total cranium and NSO; group II (IR only group), which received IR plus saline; group III (control group of NSO), which received saline and did not receive NSO or IR; and group IV (control group), which received only sham IR. Before total cranium IR, all rats were anesthetized by the administration of $80 \mathrm{mg} / \mathrm{kg}$ of ketamine $\mathrm{HCl}$ (Pfizer Ilac, Istanbul, Turkey) and placed on a tray in the prone position. The rats in the IR and the IR plus NSO groups received IR, using the Cobalt-60 teletherapy unit (Picker, C9, Maryland, NY) from a source-to-surface distance of $80 \mathrm{~cm}$ by $535 \mathrm{~cm}$ anterior fields with the total cranium gamma IR as a single dose of $5 \mathrm{~Gy}$, whereas the rats in the control and sham control groups received sham IR. The dose rate was $0.49 \mathrm{~Gy} / \mathrm{min}$. The central axis dose was calculated at a depth of $0.5 \mathrm{~cm}$. This study was approved by the local ethics committee of the Gaziantep University.

\section{Biochemical analysis}

Ten days after IR, all animals were killed by decapitation, and their heart tissues were removed. The heart tissues were homogenized in physiological saline solution (IKANERKE, GmBH KB D-79219, Staufen, Germany). The homogenate was centrifuged at 10,000 $\mathrm{g}$ for 1 hour to remove debris. The clear supernatant was collected, and all assays were carried out on this fraction. All the procedures were performed at $48^{\circ} \mathrm{C}$.

Total Antioxidant Status (TAS) and Total Oxidant Status (TOS) levels were measured using a method that was introduced by Erel. ${ }^{10}$ The results were expressed as a millimolar Trolox equivalent per liter for TAS and micromolar hydrogen peroxide equivalent per liter for TOS. The ratio of TOS to TAS was accepted as the Oxidative Stress Index (OSI). For the calculation, the resulting unit of TAS was converted to $\mu \mathrm{mol} / \mathrm{gr}$ protein, and the OSI value was calculated according to the following formula: ${ }^{11}$

OSI (arbitrary unit $)=\left[\mathrm{TOS}\left(\mu \mathrm{mol} \mathrm{H}_{2} \mathrm{O}_{2}\right.\right.$ equivalent/gr protein)/ TAS ( $\mu$ molTrolox equivalent/gr protein)] $\times 100$.

Paraoxonase (PON) activity was measured; the rate of paraoxon hydrolysis was measured by monitoring the increase by absorbance at $412 \mathrm{~nm}$ at $37^{\circ} \mathrm{C}$. The amount of generated p-nitrophenol was calculated from the molar absorptivity coefficient at $\mathrm{pH} 8$, which was $17,000 \mathrm{M} / \mathrm{cm} .{ }^{12}$ PON activity was expressed as U/gr protein. Phenylacetate was used as a substrate to measure Arylesterase (ARE) activity by monitoring the increase in absorbance at $270 \mathrm{~nm}$ at $37^{\circ} \mathrm{C}$. Activity was calculated from the molar absorptivity coefficient of the produced phenol, which was $1310 \mathrm{M} / \mathrm{cm} \cdot{ }^{13}$ Ceruloplasmin (CER) enzymatic activity was measured according to Erel's method. ${ }^{14}$ The results are expressed as U/gr protein. The Sulhydryl group $(-\mathrm{SH})$ of the liver tissue were assayed according to Ellman's method, as modified by Hu et al. ${ }^{15}$ The results are expressed as $\mathrm{mmol} / \mathrm{gr}$ protein. Lipid hydroperoxide $(\mathrm{LOOH})$ levels were measured using the ferrous ion oxidation-xylenol orange method, and the results are expressed as $\mu \mathrm{mol} / \mathrm{gr}$ protein. ${ }^{16}$

\section{Statistical analyses}

All of the statistical analyses were performed using SPSS 23 for Windows (SPSS Inc., Chicago, IL, USA). Distribution of data was evaluated using the Shapiro-Wilk test or Kolmogorov-Smirnov test. Non-normally distributed data were shown as median (quartile deviation). The Kruskal Wallis test and Dunn's multiple comparison test were used to compare variables that are not normally distributed in four groups. $p<0.05$ was considered significant.

\section{Results}

In Tables 1 and 2, oxidant and antioxidant variables are sorted by groups. In the rat heart tissues in the IR only group (group II), LOOH, TOS, and OSI levels were found to be higher, ARE activity and TAS levels were found to be lower than all of the other groups $(\mathrm{p}<0.01)$. It is remarkable that oxidative stress and antioxidant activity in the group that received NSO and received IR was similar to that which received the sham IR and the control group. 
Table 1 - Anti-Oxidative parameters of groups

\begin{tabular}{|c|c|c|c|c|c|}
\hline Groups & ARE (U/g protein) & CER (U/g protein) & $\begin{array}{l}\text { Total-SH (mmol/ } \\
\text { gr protein) }\end{array}$ & $\begin{array}{c}\text { TAS (mmol } \\
\text { Trolox equivalent/ } \\
\text { gr protein) }\end{array}$ & PON (U/g protein) \\
\hline $\begin{array}{l}\text { IR plus NSO } \\
\text { (group I) }\end{array}$ & $9.55(0.53)$ & $103.4(5.6)$ & $0.059(0.01)$ & $0.064(0.02)$ & $1.18(0.2)$ \\
\hline $\begin{array}{l}\text { IR } \\
\text { (group II) }\end{array}$ & $9.15(0.47)$ & $95.6(5.0)$ & $0.056(0.01)$ & $0.037(0.01)$ & $1.19(0.1)$ \\
\hline $\begin{array}{l}\text { Control } \\
\text { (group III) }\end{array}$ & $9.45(0.48)$ & $100.4(5.8)$ & $0.053(0.01)$ & $0.055(0.01)$ & $1.08(0.2)$ \\
\hline $\begin{array}{l}\text { Sham Control } \\
\text { (group IV) }\end{array}$ & $9.73(0.33)$ & $99.1(1.9)$ & $0.054(0.01)$ & $0.054(0.01)$ & $0.97(0.1)$ \\
\hline $\mathrm{p}$ value & $0.013^{*}$ & 0.051 & 0.091 & $0.001^{*}$ & $0.019^{*}$ \\
\hline
\end{tabular}

Table 2 - Oxidative parameters of groups

\begin{tabular}{|c|c|c|c|}
\hline Groups & $\mathrm{LOOH}(\mu \mathrm{mol} / \mathrm{gr}$ protein) & $\begin{array}{c}\text { TOS ( } \mu \text { mol } \mathrm{H} 2 \mathrm{O} 2 \text { equivalent/ } \\
\text { gr protein) }\end{array}$ & OSI (ArbitraryUnit) \\
\hline $\begin{array}{l}\text { IR plus NSO } \\
\text { (group I) }\end{array}$ & $1.15(0.08)$ & $1.80(0.22)$ & $3.18(0.8)$ \\
\hline $\begin{array}{l}\text { IR } \\
\text { (group II) }\end{array}$ & $1.71(0.06)$ & $3.30(0.33)$ & $8.50(1.1)$ \\
\hline $\begin{array}{l}\text { Control } \\
\text { (group III) }\end{array}$ & $1.06(0.01)$ & $1.61(0.37)$ & $2.96(0.8)$ \\
\hline $\begin{array}{l}\text { Sham Control } \\
\text { (group IV) }\end{array}$ & $1.02(0.05)$ & $1.79(0.23)$ & $3.07(0.8)$ \\
\hline$p$ value & $0.001^{*}$ & $0.001^{*}$ & $0.001^{*}$ \\
\hline
\end{tabular}

Level of PON in the rat heart tissues in the sham control group (group IV) was found to be lower than NSO (group I) and IR (group II) $(p<0.05)$. It is believed that this difference might be due to oral administration (saline or NSO). No statistical difference was detected among the groups (I, II, III, and IV) with respect to the levels of total-SH and enzyme activity of CER in heart tissues of the rats ( $p>0.05)$. Table 3 contains multiple statistical comparisons of variables among the groups. Highness of oxidative stress parameters and lowness of antioxidant activity in the IR group are remarkable. The group that received NSO and received
IR did not differentiate much from the sham control and control groups.

\section{Discussion}

The results of the present study support the research hypothesis that the systemic administration of NSO would reduce oxidative damage in irradiated heart tissues in an experimental rat model. In vivo when ROS occurs, it has been reported that the development of certain diseases may be prevented due to the presence of various antioxidants, 
Table 3 - Multiple comparisons of groups

\begin{tabular}{|c|c|c|c|c|c|c|}
\hline Variables & IR-Control & IR-NSO & IR-Sham & Control-NSO & Control-Sham & NSO-Sham \\
\hline ARE & $0.035^{*}$ & $0.028^{*}$ & $0.002^{*}$ & 0.982 & 0.315 & 0.312 \\
\hline TOS & $0.001^{*}$ & $0.001^{*}$ & $0.001^{*}$ & 0.607 & 0.763 & 0.839 \\
\hline TAS & $0.009^{*}$ & $0.001^{*}$ & $0.006^{*}$ & 0.273 & 0.880 & 0.346 \\
\hline OSI & $0.001^{*}$ & $0.001^{*}$ & $0.001^{*}$ & 0.890 & 0.880 & 0.770 \\
\hline $\mathrm{LOOH}$ & $0.001^{*}$ & $0.005^{*}$ & $0.001^{*}$ & 0.513 & 0.303 & 0.087 \\
\hline PON & 0.269 & 0.850 & $0.005^{*}$ & 0.357 & 0.093 & $0.008^{*}$ \\
\hline
\end{tabular}

which are enzymatic and non-enzymatic, such as GSH-Px, SOD, vitamin E, melatonin, and zinc, all of which may be able to reduce the deleterious effects of ROS with advancing age. ${ }^{17}$ It is important to protect normal tissues in the treatment area. The nature and extent of such side effects depends on the radiation dose and the sensitivity of the irradiated organs. A radiation-induced increase in xanthine oxidase activity, an oxidant enzyme, was prevented by NSO/TQ. Results of this study are in agreement with the results of the previous study with melatonin, ${ }^{4}$ ginkgo biloba, L-carnitine, and vitamin $\mathrm{E}$, which prevented a radiationinduced increase in xanthine oxidase activity in rats. ${ }^{18}$

Radioprotective agents are synthetic compounds or natural products that are applied shortly before irradiation in order to reduce the damage caused by radiation. Various studies related to the radioprotective agents are ongoing. Herbal preparations are currently becoming popular and $\mathrm{NSO}$ is only one of them. In one study, Floyd et al. ${ }^{19}$ found that peroxynitrite levels that indicate nitrosative stress increased in the irradiation only group when compared to the groups treated with NSO or TQ. For many centuries, NSO has been widely used as a traditional medicine for a wide range of diseases. NSO has been confirmed to have antioxidant properties by cleansing ROS/RNS. ${ }^{20}$ Many chemical components contained in NSO, such as flavonoids, fatty acids, sterols, and other volatile oils, are responsible for its antioxidant effect. NSO and TQ, the volatile component of NSO seed, were shown to improve antioxidant capacity induced by several agents in different animal tissues by suppressing oxidative/nitrosative stress, Nitric oxide ( $\mathrm{NO}^{\bullet}$ ) overproduction, and inducible NOS expression. Abdel-Zaher et al. ${ }^{21}$ reported that NSO can protect the brain against tramadol-induced tolerance and dependence in mice through the blocking of $\mathrm{NO}^{\bullet}$ overproduction and oxidative/nitrosative stress induced by the medicine.

Fathy et al. ${ }^{22}$ have shown the chemopreventive effects of NSO by showing the protective effect of NSO on diethylnitrosamine-induced hepatocarcinogenesis in rats by inhibition of the NOS pathway. Umar et al. ${ }^{23}$ have demonstrated the antiarthritic ability of TQ in collagen-induced arthritis. They found that TQ significantly suppressed the increase of LPO products, $\mathrm{NO}^{*}$, and myeloperoxidase activity; enhanced the activity of antioxidant enzymes; eliminated the accumulation and activation of polymorphonuclear cells; and maintained homeostasis in the cytokine imbalance. Gilhotra et al. ${ }^{24}$ investigated the role of GABAergic and nitriergic modulation in the antianxiety effect of TQ in mice under unstressed and stressed conditions, and demonstrated that TQ decreased plasma nitrite, a stable metabolite of $\mathrm{NO}^{\bullet}$ in stressed mice, and showed anxiolytic effects.

Both in vitro and in vivo anti-inflammatory, antioxidant, and antineoplastic effects of NSO and TQ were reported in many studies. The antioxidant/anti-inflammatory effects of these agents have been studied in a variety of disease models, including cancer, sepsis, atherosclerosis, asthma, and carcinogenesis. ${ }^{25}$

\section{Study Limitations}

The small sample size is the main limitation of our study.

\section{Conclusion}

NSO is likely to be a valuable substance to protect against gamma-IR and/or may be used as an 
antioxidant against oxidative stress and other severe side effects occurring in the patients treated with radiotherapy.

\section{Author contributions}

Conception and design of the research: Kaplan M, Demir E. Acquisition of data: Kaplan M, Demir E, Yavuz F, Kaplan GI, Taysi MR. Analysis and interpretation of the data: Kaplan M, Demir E, Yavuz F, Kaplan GI, Taysi MR. Statistical analysis: Kaplan M, Yavuz F, Taysi MR, Sucu MM. Obtaining financing: Kaplan M. Writing of the manuscript: Kaplan M, Yavuz F, Kaplan GI. Critical revision of the manuscript for intellectual content: Kaplan M, Demir E, Taysi MR, Sucu MM. Supervision / as the major investigador: Kaplan $\mathrm{M}$.

\section{References}

1. Prasanna PG, Stone HB, Wong RS,CapalaJacek, Bernhard EJ, Vikram $\mathrm{B}$, et al. Normal tissue protection for improving radiotherapy: where are the gaps? Transl Cancer Res. 2012;(1):35-48.

2. Sies H. Strategies of antioxidant defense. Eur J Biochem. 1993; 215(2):213-9.

3. Cadenas E. Biochemistry of oxygen toxicity. Annu Rev Biochem.1989;58:79-110

4. Taysi S, Memisogullari R, Koc M,Yazıcı AT, Aslankurt M, Gumustekin K, et al. Melatonin reduces oxidative stress in the rat lens due to radiationinduced oxidative injury. Int J Radiat Biol. 2008; 84(10):803-8.

5. Taysi S, Abdulrahman ZK, Okumus S, Demir E, Demir T, Akan M, et al. The radioprotective effect of Nigella sativa on nitrosative stress in lens tissue in radiation-induced cataract in rat. Cutan Ocul Toxicol. 2015; 34 (2):101-6

6. Taysi S, Cikman O, Kaya A, Demircan B, Gumustekın K, Yllmaz A, et al. Increased oxidant stress and decreased antioxidant status in erythrocytes of rats fed with zinc-deficient diet. Biol Trace Elem Res. 2008;123(1-3):161-7.

7. Pijnenborg R, Vercruysse L, Hanssens M. The uterine spiral arteries in human pregnancy: facts and controversies. Placenta. 2006; 27(910):939-58.

8. Salem ML. Immunomodulatory and therapeutic properties of the Nigella sativa L. seed. Immunopharmacol. 2005;5(13-14):1749-70.

9. Ahlatci A, Kuzhan A, Taysi S, Demirtas OC, Alkis HE, Tarakcioglu M, et al. Radiation-modifying abilities of Nigella sativa and thymoquinone on radiation-induced nitrosative stress in the brain tissue. Phytomedicine. $2014 ; 21(5): 740-4$

10. Erel O. A novel automated direct measurement method for total antioxidant capacity using a new generation, more stable ABTS radical cation. Clin Biochem. 2004; 37(4):277-85.

11. Esen C, Alkan BA, Kirnap M, Akgül O, Isıkoglu S, Erel O. The effects of chronic periodontitis and rheumatoid arthritis on serum and gingival crevicular fluid total antioxidant/oxidant status and oxidative stress index. J Periodontol. 2012; 83(6):773-9.

12. Eckerson HW, Wyte CM, La Du BN. The human serum paraoxonase/ arylesterase polymorphism. Am J Hum Genet. 1983;35(6):1126-38.

\section{Potential Conflict of Interest}

No potential conflict of interest relevant to this article was reported.

\section{Sources of Funding}

There were no external funding sources for this study.

\section{Study Association}

This study is not associated with any thesis or dissertation work.

\section{Ethics approval and consent to participate}

This study was approved by the Ethics Committee on Animal Experiments of the Gaziantep University under the protocol number 2016/15.

13. Haagen L, BrockA. A new automated method for phenotypingarylesterase (EC 3.1.1.2) based upon inhibition of enzymatic hydrolysis of 4-nitrophenyl acetate by phenyl acetate. Eur J Clin Chem Clin Biochem. 1992; 30(7):391-5.

14. Erel O. Automated measurement of serum ferroxidase activity. Clin Chem.1998; 44(11):2313-9.

15. Ellman GL. Tissue sulfhydryl groups. Arch Biochem Biophys. 1959; 82(1):70-7.

16. Nourooz-Zadeh J. Ferrous ion oxidation in presence of xylenol orange for detection of lipid hydroperoxides in plasma. Methods Enzymol. 1999;300:58-62.

17. Karslioglu I, Ertekin MV, Kocer I, Taysi S, Sezen O, Gepdiremen A, et al. Protective role of intramuscularly administered vitamin E on the levels of lipid peroxidation and the activities of antioxidant enzymes in the lens of rats made cataractous with gammairradiation. Eur J Ophthalmol.2004; 14(6):478-85.

18. Manikandan R, Thiagarajan R, Beulaja S, Chindhu S, Mariammal $\mathrm{K}$, Sudhandiran G, et al. Anti-cataractogenic effect of curcumin and aminoguanidine against selenium-induced oxidative stress in the eye lens of Wistar rat pups: an in vitro study using isolated lens. Chem Biol Interact.2009;18(2):202-9.

19. Taysi S, Okumus S, Ezirmik S, Uzun N, Yılmaz A, Akyüz M, et al. The protective effects of L-carnitine and vitamin $\mathrm{E}$ in rat lenses in irradiation-induced oxidative injury. Adv Clin Exp Med. 2011;20(1):1521.

20. Floyd RA. Neuroinflammatory processes are importantin neurodegenerative diseases: a hypothesis to explain the increased formation of reactive oxygen and nitrogen species as major factors involved in neurodegenerative disease development. Free Radic Biol Med. 1999;6(9-10):1346-55.

21. Abdel-Zaher AO, AbdelRahman MS, Elwasei FM. Protective effect of Nigella sativa oil against tramadol-induced tolerance and dependence in mice: role of nitric oxide and oxidative stress. Neurotoxicology. 2011;32(6):725-33.

22. Fathy M, Nikaido T. In vivo modulation of iNOS pathway in hepatocellular carcinoma by Nigella sativa. Environ Health Prev Med.2013;18:377-85. 
23. Umar S, Zargan J, Umar K, Ahmad S, Katiyar CK, Khan HA. Modulation of the oxidative stress and inflammatory cytokine response by thymoquinone in the collagen induced arthritis in Wistar rats. Chem Biol Interact.2012;197(1):40-6.

24. Gilhotra N, Dhingra D. Thymoquinone produced antianxiety like effects in mice through modulation of GABA and NO levels. Pharmacol Rep. 2011;63(3):660-9..
25. Gholamnezhad Z, Havakhah S, BoskabadyMH. Preclinical and clinical effects of Nigella sativa and its constituent, thymoquinone: A review. J Ethnopharmacol. 2016 Aug 22;190:372-86. 